Endocrinol. Japon. 1984, 31 (4), 451-457

\title{
The Thyroid Reserve in Children with Chronic Lymphocytic Thyroiditis Revealed by the Thyrotropin-Releasing Hormone and Thyroid-Stimulating Hormone Tests
}

\author{
Nozomu SASAKI, Toshiaki TSUYUSAKI, KAZUnori SANAYAMA \\ Hiroaki INOMATA, Hiroo NIIMI aNd Hironori NAKAJIMA
}

Department of Pediatrics, School of Medicine, Chiba University, Chiba 280

\begin{abstract}
Serum thyroid hormone and TSH concentrations were measured before and after the administration of TRH $(10 \mu \mathrm{g} / \mathrm{kg}$ body weight) and bovine TSH (10 IU) in 14 children with chronic lymphocytic thyroiditis.

The TRH test showed that the responsiveness of TSH was positively correlated with the basal TSH $(\mathrm{P}<0.001)$ and inversely with the increase in serum thyroid hormones, for $\Delta \mathrm{T} 3(\mathrm{P}<0.05)$ and for $\Delta \mathrm{T} 4 \quad(\mathrm{P}<0.001)$. Overall, the patients had significantly lower mean values for basal T4, but not for T3.

The TSH test revealed that the $\Delta \mathrm{T} 3$ was positively correlated with $\Delta \mathrm{T} 4 \mathrm{P}<$ 0.05). $\triangle \mathrm{T} 3$ after TSH administration was positively correlated with it after TRH $(\mathrm{P}<0.05)$.

The patients were divided into three groups on the basis of their peak TSH values after TRH administration. In Group 1 (peak value below $40 \mu \mathrm{U} / \mathrm{ml}$; $\mathrm{N}=5)$; T3 increased significantly after TRH and TSH administrations $(\mathrm{P}<0.05$ and $\mathrm{P}<0.025$, respectively). In addition, $\Delta \mathrm{T} 4$ was significant after TSH administration. In Group 2 (peak TSH above 40 and less than $100 \mu \mathrm{U} / \mathrm{ml} ; \mathrm{N}=$ 6 ) ; only $\triangle \mathrm{T} 3$ after TRH was significant $(\mathrm{P}<0.05)$. In Group 3 (peak TSH above $100 \mu \mathrm{U} / \mathrm{ml} ; \mathrm{N}=3)$; the response of thyroid hormones was blunted. Thus, the thyroid hormone responses to endogenous TSH coincided with that to exogenous TSH, and the exaggerated TSH response to TRH indicates decreased thyroid reserve.
\end{abstract}

Chronic lymphocytic thyroiditis (CLT) has been reported to be the most frequent cause of struma and hypothyroidism in older children and adolescents (Mäenpää, 1982 ; Fisher, 1973; Hung et al., 1973; Rallison et al., 1975; Inoue et al., 1975). Clinically, however, most of the patients show subclinical or latent hypothyroidism with an isolated elevation of TSH or an exaggerated response of TSH to TRH in the presence of normal or low normal serum $\mathrm{T} 4$ and

Received March 12, 1984 normal T3 levels. In this situation, the thyroid reserve is thought to be decreased and peripheral conversion of $\mathrm{T} 3$ from $\mathrm{T} 4$ is considered to be increased. However, the correlation between the degree of exaggerated response of TSH to TRH and the thyroid reserve, and the responsiveness of T3 and T4 to TSH, has not been clearly revealed in children with CLT. In order to clarify the thyroid reserve function in children with CLT, the responsiveness of T3 and $\mathrm{T} 4$ to endogeneous and exogeneous TSH was investigated. 


\section{Materials and Methods}

\section{Subjects}

One male and 13 female patients with CLT aged between five and 13 were investigated. There were no clinical symptoms in any case except moderately enlarged thyroid. The diagnosis was made on the basis of clinical and laboratory data and histologically confirmed in all cases by needle biopsy.

\section{Methods}

For the TRH test, $10 \mu \mathrm{g} / \mathrm{kg}$ body weight of TRH was injected intravenously. Blood samples were taken before, as well as at $15,30,60,90$ and 120 minutes after injection. Serum TSH was measured in each sample by RIA (Daiichi Laboratory Co., Japan), and serum T3 and T4 were measured before and at 120 minutes after TRH administration by RIA (T3-RIA and T4RIA kits., Dainabot Co.).

The TSH test was performed by intramuscularly injecting 10 U.S.P. of bovine TSH (bTSH, for those patients weighing less than $40 \mathrm{~kg}, 0.25$ u.s.p. per $\mathrm{kg}$ body weight was used; Thytropar Armor Co.) Blood samples were taken before and at 24 hours after injection. Serum T3 and T4 were measured as mentioned above. The TSH test was carried out two weeks after the TRH test.

Serum was separated by centrifugation and stored by deep-freezing until assay. All samples were run in the same assay.

The normal serum levels of T3, T4 and TSH are from 98 to $202 \mathrm{ng} / \mathrm{dl}$, from 4.5 to $13 \mu \mathrm{g} / \mathrm{dl}$ and less than $10 \mu \mathrm{U} / \mathrm{ml}$, respectively. Normal response of TSH to TRH is between 10 and 40 $\mu \mathrm{U} / \mathrm{ml}$. The increases in $\mathrm{T} 3$ and $\mathrm{T} 4$ in res-

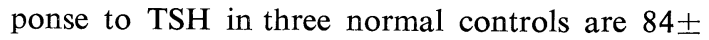
$17 \mathrm{ng} / \mathrm{dl}$ and $6.0 \pm 1.3 \mu \mathrm{g} / \mathrm{dl}$, respectively. All data are given as the mean \pm SD. Statistical analyses were made by Student's $t$-test. The correlation calculations were made by the usual least squares method.

\section{Results}

\section{TRH test}

The basal serum T3 level was $141 \pm 36$ $\mathrm{ng} / \mathrm{dl}$, and rose significantly to $176 \pm 46 \mathrm{ng} /$ dl after TRH administration $(\mathrm{P}<0.05)$. The overall increase in $\mathrm{T} 3(\Delta \mathrm{T} 3)$ was $31 \pm 20$ $\mathrm{ng} / \mathrm{dl}$.

The serum T4 levels before and after TRH administration were $8.2 \pm 3.0 \mu \mathrm{g} / \mathrm{dl}$ and $8.8 \pm 3.1 \mu \mathrm{g} / \mathrm{dl}$, respectively, showing no significant increase $\Delta \mathrm{T} 4$. The maximum response of TSH to TRH was noted at 15 or 30 minutes after TRH administration, and the peak values (Max. TSH) were within the range of $14-100 \mu \mathrm{U} / \mathrm{ml}$ in 12 cases, and that was over $100 \mu \mathrm{U} / \mathrm{ml}$ in

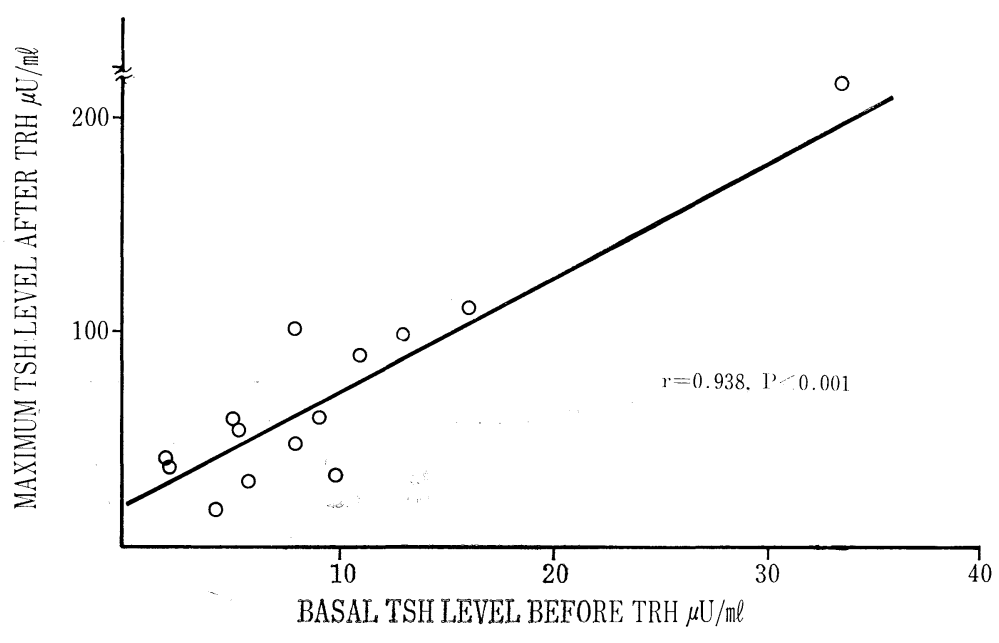

Fig. 1. The correlation between the TSH response to TRH and basal serum TSH level. The responsiveness of TSH (Max. TSH) to TRH was positively correlated with the basal TSH (b$\mathrm{TSH})$ values. 
two cases in which the basal TSH levels (b-TSH) were significantly elevated. The TSH response was exaggerated in four out of seven patients whose basal TSH level was between 5 and $10 \mu \mathrm{U} / \mathrm{ml}$. The responsiveness of TSH to TRH was positively correlated with the b-TSH level $(\mathrm{r}=0.938, \mathrm{P}<0.001)$ (Fig. 1) and inversely with the basal T4 level ( $\mathrm{r}=-0.662, \mathrm{P}<0.001$ ) (Fig. 2), but not with the basal T3 level. However, $\Delta \mathrm{T} 3$ after TRH was inversely correlated with the responsiveness of TSH $(\mathrm{r}=-0.626, \mathrm{P}<0.05)$.

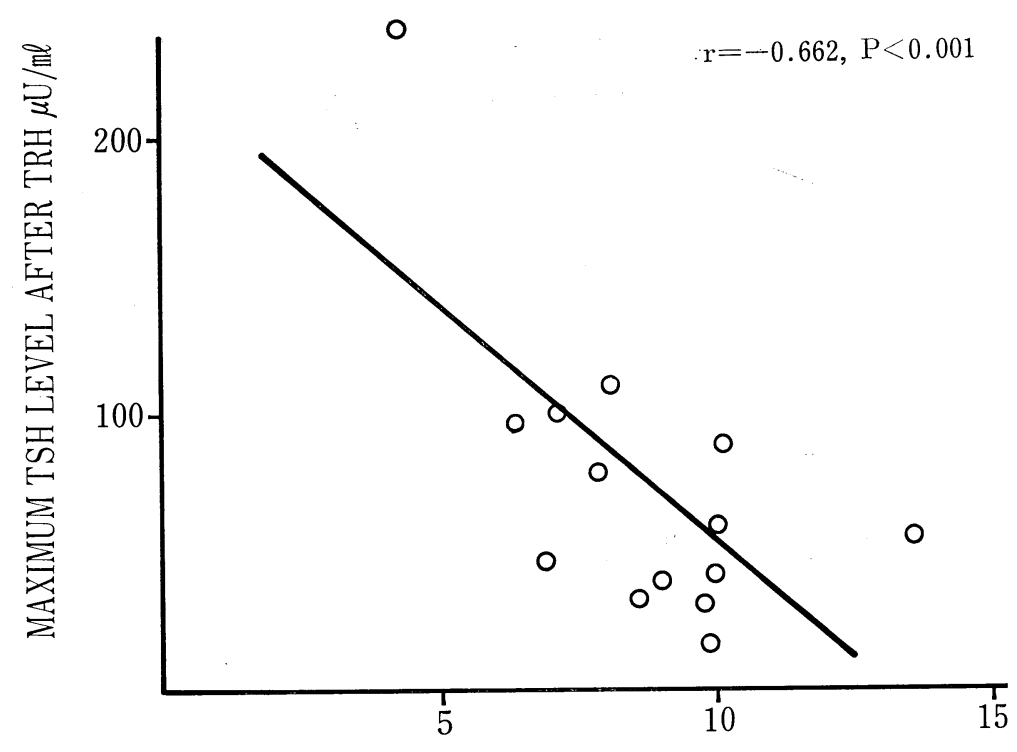

T4 $\mu \mathrm{g} / \mathrm{d} l$

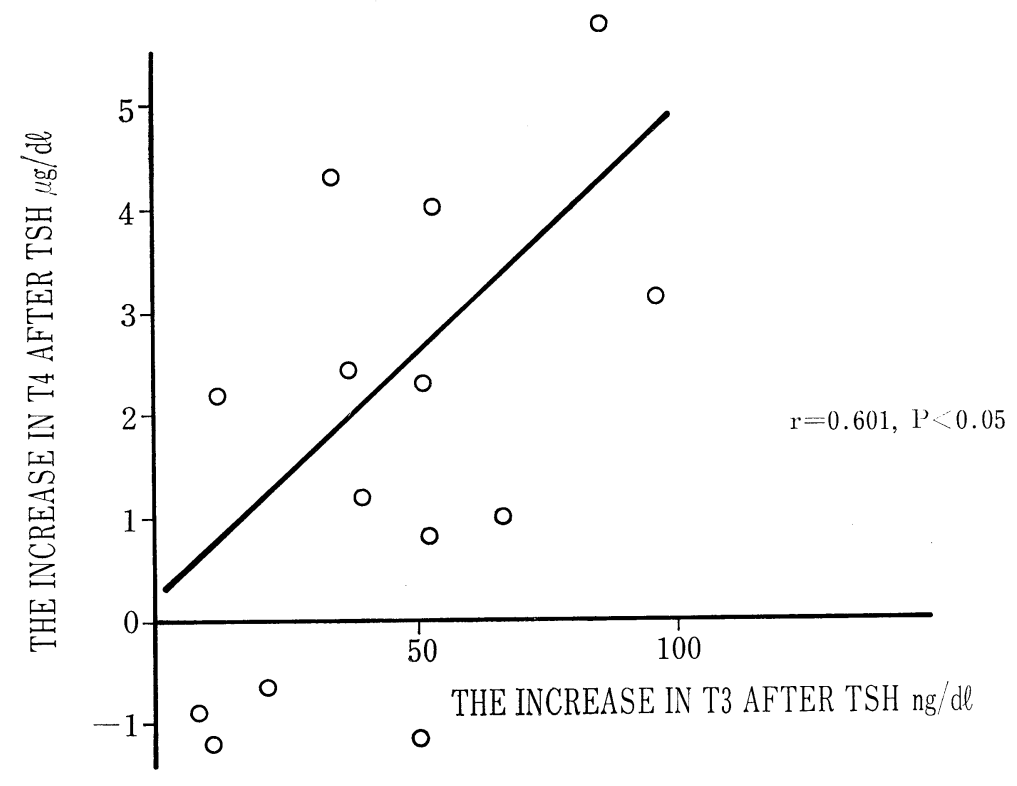

Fig. 2. The correlation between the TSH response to TRH and basal serum T4 level. The responsiveness of TSH (Max. TSH) to TRH was inversely correlated with basal T4 levels.
Fig. 3. The correlation between the $\mathrm{T} 3$ response to TSH and that of T4 to TSH. Positive correlation was observed between the increase in $\mathrm{T} 3$ and that of T4 after TSH administration. 

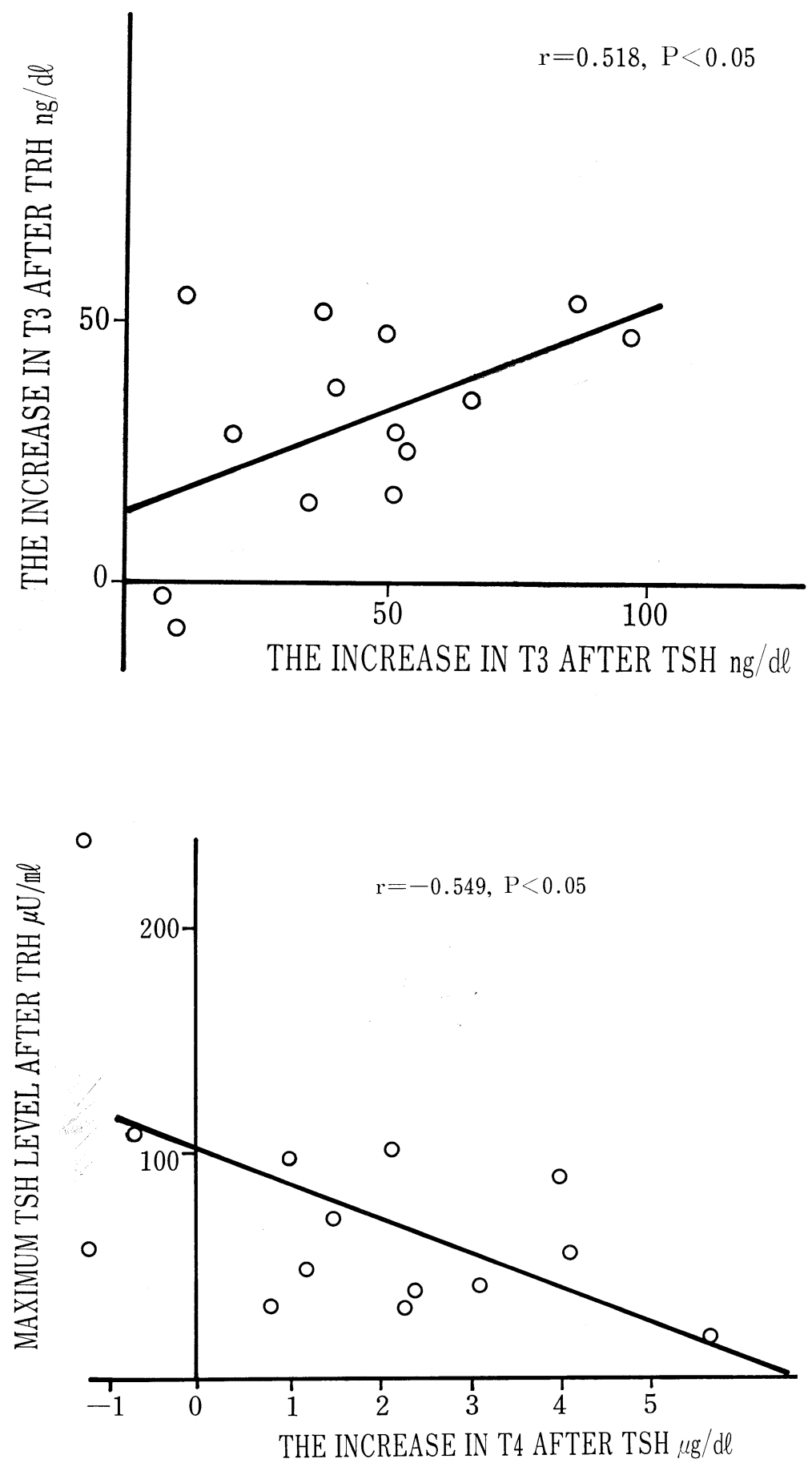

Fig. 4. The correlation between the $T_{3}$ response to TRH and to TSH. The responsiveness of T3 after TRH was positively correlated with that of T3 after TSH.
Fig. 5. The correlation between the TSH response to TRH and basal serum T4 level. The responsiveness of TSH (Max. TSH) to TRH was inversely correlated with basal T4 levels. 
Table 1. The serum T3 and T4 levels, and the increases in T3 and T4 before and after TRH and TSH administrations.

The patients were divided into three groups according to the responsiveness of TSH (Max. TSH) to TRH (Group 1: below $40 \mathrm{uU} / \mathrm{ml}$, Group 2: above 50 and less than $100 \mathrm{uU} / \mathrm{ml}$, Group 3: above $100 \mathrm{uU} / \mathrm{ml}$ ). T3 elevated significantly after TRH and TSH administrations $\left(^{*}: \mathrm{P}<0.05,{ }^{* *}: \mathrm{P}<0.001\right)$, and T4 rose significantly to TSH $(* * *: \mathbf{P}<0.025)$ in Group 1 . In Group 2 , the response of T3 to TRH was significant (**** $: \mathrm{P}<0.025)$. A statistical difference was noticed between $a$ and $a^{\prime}(P<0.05), b$ and $b^{\prime}(P<0.025), c$ and $c^{\prime}(P<0.025)$, respectively.

\begin{tabular}{|c|c|c|c|c|c|c|c|}
\hline \multicolumn{2}{|c|}{ Group } & \multicolumn{3}{|c|}{$\mathrm{T} 4 \mu \mathrm{g} / \mathrm{dl}$} & \multicolumn{3}{|c|}{$\mathrm{T} 3 \mathrm{ng} / \mathrm{dl}$} \\
\hline Max. TSH & $\mathrm{I} \quad \mu \mathrm{U} / \mathrm{ml}$ & Before & After & $\mathrm{T} 4$ & Before & After & T3 \\
\hline G1 & TRH test & $9.4 \pm 0.6$ & $10.2 \pm 0.4$ & $0.7 \pm 0.6$ & $147 \pm 20$ & $189 \pm 33^{*}$ & $42 \pm 19 a$ \\
\hline $\begin{array}{l}\leqq 40 \\
\mathrm{n}=5\end{array}$ & TSH test & $9.3 \pm 0.9$ & $12.4 \pm 2.4^{* * *}$ & $3.1 \pm 1.5 \mathrm{c}$ & $169 \pm 15$ & $230 \pm 22 * *$ & $66 \pm 27 b$ \\
\hline $\mathrm{G} 2$ & TRH test & $9.0 \pm 2.8$ & $9.5 \pm 2.5$ & $0.9 \pm 0.9$ & $155 \pm 25$ & $191 \pm 20^{* * *}$ & $36 \pm 15$ \\
\hline $\begin{array}{r}41 \sim 99 \\
\mathrm{n}=6\end{array}$ & TSH test & $9.7 \pm 1.6$ & $11.6 \pm 2.1$ & $2.0 \pm 1.9$ & $150 \pm 37$ & $195 \pm 42$ & $45 \pm 22$ \\
\hline G3 & TRH test & $4.5 \pm 3.6$ & $4.5 \pm 3.1$ & $0.1 \pm 0.5$ & $117 \pm 64$ & $122 \pm 74$ & $5 \pm 20 \mathrm{a}^{\prime}$ \\
\hline$\underset{\substack{\mathrm{n}=3\\
}}{\geqq 100}$ & TSH test & $4.8 \pm 3.0$ & $3.9 \pm 3.1$ & $0.9 \pm 0.3 c^{\prime}$ & $104 \pm 56$ & $100 \pm 43$ & $13 \pm 7 b^{\prime}$ \\
\hline
\end{tabular}

\section{TSH test}

Serum T3 and T4 levels before and after TSH administration were $147 \pm 41 \mathrm{ng} / \mathrm{dl}, 8.5$ $\pm 2.6 \mu \mathrm{g} / \mathrm{dl}$, and $192 \pm 59 \mathrm{ng} / \mathrm{dl}, 10.2 \pm 4.0$ $\mu \mathrm{g} / \mathrm{dl}$, respectively. The responsiveness of both T3 and T4 to TSH was not significant. However, a significant positive correlation was observed between $\Delta \mathrm{T} 3$ and $\Delta \mathrm{T} 4(\mathrm{P}<0.05)$ (Fig. 3).

The correlation between the TSH test and TRH test.

$\triangle \mathrm{T} 3$ after TSH and TRH administrations was positively correlated $(\mathrm{P}<0.05)$ (Fig. 4).

The elevation of TSH in response to TRH administration was inversely correlated with $\Delta \mathrm{T} 3$ and $\Delta \mathrm{T} 4$ after $\mathrm{TSH}$ injection $(\mathrm{P}<$ 0.05) (Fig. 5).

The responsiveness of $\mathrm{T} 3$ and $\mathrm{T} 4$ after TSH and TRH administration was compared among the three groups of patients (Table 1.).

In Group 1, the serum T3 increased significantly after TRH and TSH administrations from $147 \pm 20 \mathrm{ng} / \mathrm{dl}$ to $189 \pm 33 \mathrm{ng} / \mathrm{dl}$ $(\mathrm{P}<0.05)$, and from $169 \pm 15 \mathrm{ng} / \mathrm{dl}$ to $230 \pm$
$22 \mathrm{ng} / \mathrm{dl}(\mathrm{P}<0.001)$, respectively. However, T4 rose significantly only after the TSH administration, from $9.3 \pm 0.9 \mu \mathrm{g} / \mathrm{dl}$ to 12.4 $\pm 2.4 \mu \mathrm{g} / \mathrm{dl} \quad(\mathrm{P}<0.025)$. In Group 2, T3 increased significantly from $155 \pm 25 \mathrm{ng} / \mathrm{dl}$ to $191 \pm 20 \mathrm{ng} / \mathrm{dl}$ after TRH administration $(\mathrm{P}<0.025)$, but neither T3 nor T4 showed any significant response to TSH. In Group 3 , no significant increases in $\mathrm{T} 3$ and $\mathrm{T} 4$ were observed in response to either TRH or TSH administration.

\section{Discussion}

The present investigation confirmed that the thyroid function in subclinical hypothyroid children with CLT also shows low normal values for basal T4 levels with normal blood T3 levels as reported in adults (Evered et al., 1973; Tunbridge et al., 1977; Sawin et al., 1979; Bastenie et al., 1980; Tunbridge et al., 1981; Staub et al., 1983). This condition is usually called preclinical or subclinical hypothyroidism. The definition 
is based on normal basal values for T4, normal or elevated basal TSH levels and exaggerated response to TRH (Gordin et al., 1974; Hall et al., 1972; Vagenakis et al., 1974; Bigos et al., 1978), or based on elevated TSH only (Evered et al., 1973; Sawin et al., 1979; Tunbridge et al., 1981).

To evaluate the thyroid reserve, the thyroid hormone response was assessed by exogenous bovine TSH and by endogenous TSH released after TRH administration. After iv TRH administration, serum T3 levels have been reported to reach a peak in two to three hours (Hooper et al., 1978; Holmes et al., 1980; Shenkman et al., 1973; Vagenakis et al., 1974) and in three to six for T4 (Hooper et al., 1978; Holmes et al., 1980). On the other hand, following $10 \mathrm{IU}$ bTSH, the peak T3 values were described to be not significantly different after from two to 24 hours, and, as for T4, a peak value reached at 24 hours was not significantly different when compared with values at six to 72 hours (Uller et al., 1977). Therefore, in our study, the increases in T3 and T4 at 2 hours after TRH administration and at 24 hours after TSH administration were assessed. The degree of responsiveness of T4 to exogenous and endogenous TSH is significantly correlated with that of $\mathrm{T} 3$, and the responsiveness of $\mathrm{T} 3$ and $\mathrm{T} 4$ is inversely correlated with the basal TSH level and the response of TSH to TRH. To evaluate the thyroid reserve in relation to the pituitary TSH reserve, we classified the patients into three groups according to the TSH response to TRH. The T3 increase was still significant in patients with normal and moderately exaggerated response of TSH (less than $100 \mu \mathrm{U} / \mathrm{ml}$ ). On the other hand, the thyroid reserve of T3 was clearly abolished in patients with pronounced response of TSH to TRH, Group 3. The T4 increase following TSH stimulation was significant only in patients with normal response to TSH, Group 1, but the increase was less significant than that in normal controls. Thus, the responsiveness of T3 is maintained relatively well compared to that of T4 in a subclinical hypothyroid state. This study shows that the relatively normal serum T3 level with low normal or low T4 levels, reflected as an increase in the $\mathrm{T} 3$ to $\mathrm{T} 4$ ratio, is due not only to the increased peripheral conversion of $\mathrm{T} 4$ to $\mathrm{T} 3$, but also to the relatively well maintained $\mathrm{T} 3$ secretion from the thyroid gland in subclinical hypothyroid children with CLT. And the results of the present study demonstrate that the elevated basal or exaggerated response of TSH is a reflection of decreased thyroid hormone synthesis. And the high normal basal TSH level may suggest the decreased thyroid reserve in some patients with CLT. The impairment of thyroid reserve in patients with CLT has been thought to be the result of many pathological steps of intrathyroid hormone synthesis (Holmes et al., 1980), and it demonstrates a progressive loss of the glandular secreting function (Staub et al., 1983).

As for the histological findings in our cases, there were many variations in the destruction of epitherial cells and the infiltration of lymphoid cells. The focal thyroiditis, however, was a predominant feature in all cases except two in Group 3. The histological classification of two cases in Group 3 was the diffuse thyroiditis, and they showed the decrease thyroid function and blunted responses of thyroid hormones to TSH and TRH. However, considering our previous report on transient hypothyroidism in children with CLT (Sasaki et al., 1983), recovery from the intrathyroidal defects might occasionally take place within a short period. The precise mechanism of transient impairment remains to be clarified.

The prognostic significance of the transient overt hypothyroidism and subclinical hypothyroidism in children with CLT would be revealed by long-term follow-up. 


\section{References}

Bastenie, P. A., M. Bonnyns and L. Vanhaelst (1980). Grades of subclinical hypothyroidism in asymptomatic autoimmune thyroiditis revealed by the thyrotropin-releasing hormone test. J. Clin. Endocrinol. Metab. 51, 163-166.

Bigos, S. T., E. G. Ridgway, I. A. Kourides and F. Maloof (1978). Spectrum of pituitary alterations in mild and severe thyroid impairment. J. Clin. Endocrinol. Metab. 46, 317-325.

Evered, D. C., B. J. Ormston, P. A. Smith, R. Hall and D. Bird (1973). Grades of hypothyroidism. Br. Med. J. 1, 657-662.

Fisher, D. A. (1973). Advances in the laboratory diagnosis of thyroid disease, Part II. J. Pediatr. 82, 187-191.

Gordin, A., P. Saarinen, A. Pelkonen and B. A. Lamberg (1974). Serum thyrotrophin and the response to thyrotrophin releasing hormone in symptomless autoimmune thyroiditis and in borderline and overt hypothyroidism. Acta. Endocrinol. (Kbh) 75, 274-285.

Holmes, S. D., J. Gitlin, G. Titus and J. B. Field (1980). Effect of increase circulating thyroidstimulating hormone on in vitro thyroid-stimulating hormone stimulation of thyroid and adipose tissues. Endocrinology, 107, 1892-1899.

Hooper, M. J., J. G. Ratcliffe, W. A. Ratcliffe, J. Marshall, R. E. Young, G. Ngaei and D. G. Clark (1978). Evidence for thyroidal secretion of 3, 3',5-triiodothyroinine in man and its control by TSH. Clin. Endocrinol. (Oxf) 8, 267-273.

Hung, W., R. Chandra, G. P. Aufust and P. R. Altman (1973). Clinical, laboratory and histologic observations in euthyroid children and adolescents with goiter. J. Pediatr. 82, 10-16.

Hall, R., B. J. Ormston, G. M. Besser, R. J. Cryer and M. McKendrick (1972). The thyrotrophin-releasing hormone test in diseases of the pituitary and hypothalamus, Lancet. 1. 759-762.

Inoue, M., N. Taketani, T. Sato and H. Nakajima (1975). High incidence of chronic lymhocytic thyroiditis in apparently healthy school children; Epidemiological and clinical study. Endocrinol. Jpn. 22, 483-488.
Mäenpää, J. (1982). Juvenile goiters. Autoimmune thyroiditis. Acta Paediatria. 61, 42-62.

Rallison, M. L., B. M. Dobyns, F. R. Keating, J. E. Rall and F. H. Tyler (1975). Occurrence and natural history of chronic lymphocytic thyroiditis in childhood. J. Pediatr, 86, 675-682.

Sasaki, N., T. Tsuyusaki, H. Inomata, H. Niimi and H. Nakajima (1983). Significant fluctuation of thyroid function in children with chronic lymphocytic thyroiditis. Endocrinol. Jpn. 30, 219-228.

Sawin C. T., D. Chopra, F. Azizi, J. E. Mannix and P. Bacharach (1979). The aging thyroid; increased prevalence of elevated serum thyrotropin levels in the elderly. J.A.M.A. 242, 247-250.

Shenkman, L., T. Mitsuma and C. Hollander (1973). Methods for detection of incipient primary hypothyroidism: a comparative study. J. Clin. Endocrinol. Metab. 36, 1074-1078.

Staub, J. J., B. Noelpp, R. Gräni, E. Gemsenjäger, M. Gauenstein and J. Girard (1938). The relationship of serum thyrotropin (TSH) to the thyroid hormones after oral TSH-releasing hormone in patients with preclinical hypothyroidism. J. Clin. Endocrinol. Metab. 56, 449-453.

Tunbridge, W. M. G., D. C. Evered, R. Hall, D. Appleton, M. Brewis, F. Clark, J. Grimley Evans, E. Young, T. Bird and P. A. Smith (1977). The spectrum of thyroid diseases in a community; the Wickham survey. Clin. Endocrinol. (Oxf) 7, 481-493.

Tunbridge, W. M. G., M. Brewis, J. M. French, D. Appleton, T. Bird, F. Clark, D. C. Evered, J. Grimley Evans, R. Hall. P. Smith, J. Stephenson and E. Young (1981). Natural history of autoimmune thyroiditis. Br.' Med. J. 282, 258262.

Uller, R. P., A. J. Van Herle and I. J. Chopra (1977). Thyroidal response to graded doses of bovine thyrotropin. J. Clin. Endocrinol. Metab. 45, 312-318.

Vagenakis, A. F., Azizi, G. Portnay, L. Braverman, B. Rapoport and S. Ingbar (1974). Hyperresponse to thyrotropin-releasing hormone accompanying small decreases in serum thyroid hormone concentration. J. Clin. Invest. 54, 913-918. 